\title{
Current challenges in the management of patients with sickle cell disease - A report of the Italian experience
}

\author{
Giovanna Russo ${ }^{1 *} \mathbb{D}$, Lucia De Franceschi ${ }^{2}$, Raffaella Colombatti ${ }^{3}$, Paolo Rigano ${ }^{4}$, Silverio Perrotta ${ }^{5}$, Vincenzo Voi ${ }^{6}$, \\ Giovanni Palazzi ${ }^{7}$, Carmelo Fidone ${ }^{8}$, Alessandra Quota ${ }^{9}$, Giovanna Graziadei ${ }^{10}$, Antonello Pietrangelo ${ }^{11}$, \\ Valeria Pinto ${ }^{12}$, Giovan Battista Ruffo ${ }^{13}$, Francesco Sorrentino ${ }^{14}$, Donatella Venturelli ${ }^{15}$, Maddalena Casale ${ }^{5}$, \\ Francesca Ferrara ${ }^{11}$, Laura Sainati ${ }^{3}$, Maria Domenica Cappellini ${ }^{10}$, Antonio Piga ${ }^{16}$, Aurelio Maggio ${ }^{4}$ and \\ Gian Luca Forni ${ }^{12^{*}}$
}

\begin{abstract}
Sickle cell disease (SCD) is an inherited red blood cell disorder caused by a structural abnormality of hemoglobin called sickle hemoglobin (HbS). Clinical manifestations of SCD are mainly characterized by chronic hemolysis and acute vaso-occlusive crisis, which are responsible for severe acute and chronic organ damage. SCD is widespread in sub-Saharan Africa, in the Middle East, Indian subcontinent, and some Mediterranean regions. With voluntary population migrations, people harboring the HbS gene have spread globally. In 2006, the World Health Organization recognized hemoglobinopathies, including SCD, as a global public health problem and urged national health systems worldwide to design and establish programs for the prevention and management of SCD. Herein we describe the historical experience of the network of hemoglobinopathy centers and their approach to SCD in Italy, a country where hemoglobinopathies have a high prevalence and where SCD, associated with different genotypes including B-thalassemia, is present in the native population.
\end{abstract}

Keywords: Hemoglobin disorder, Hemoglobinopathy, Hydroxyurea, Migrants, Sickle cell screening, Sickle cell disease, Transfusion, Vaso-occlusion crisis

\section{Introduction}

The term sickle cell disease (SCD) encompasses a group of inherited red blood cell disorders caused by a structural abnormality of hemoglobin $(\mathrm{Hb})$ called sickle hemoglobin $(\mathrm{HbS})$, which originates from a single nucleotide substitution in the gene encoding ß-globin [1]. HbS is inherited in an autosomal recessive way and SCD can occur due to homozygosity for HbS (HbSS), a condition also known as sickle cell anemia (SCA), or due to compound heterozygosity with $B$-thalassemia mutations $\left(\mathrm{HbS} / \mathrm{B}^{0}\right.$-thalassemia and $\mathrm{HbS} / \mathrm{B}^{+}$-thalassemia, previously known as microdrepanocytic disease and first

\footnotetext{
*Correspondence: diberuss@unict.it; gianluca.forni@galliera.it

'Oncoematologia Pediatrica, Azienda Policlinico-Vittorio Emanuele, Università

di Catania, Via Santa Sofia 78, 95123 Catania, Italy

${ }^{12}$ Centro della Microcitemia e delle Anemie Congenite, Ospedale Galliera, Via

Volta 6, 16128 Genova, Italy

Full list of author information is available at the end of the article
}

described by Silvestroni and Bianco in 1944 [2]), and other B-globin structural variants such as $\mathrm{HbC}$ (HbSC disease) [1]. HbS is functional and soluble when oxygenated, but upon deoxygenation it polymerizes, leading to the generation of misshapen red blood cells known as sickled cells and dense erythrocytes [3]. Sickle red blood cells show: (i) abnormal membrane mechanical stability; (ii) increased membrane oxidation; (iii) activation of pro-dehydrating membrane transport pathways; and (iv) pro-adhesive molecules. The dense, rigid red blood cells are easily trapped within organs with sluggish microcirculation by their interaction with the inflammatory activated vascular endothelial cells and neutrophils. These events generate acute vaso-occlusive events, which leads to ischemic-reperfusion damage of target organs such as lung, kidney or brain [3-6].

(c) The Author(s). 2019 Open Access This article is distributed under the terms of the Creative Commons Attribution 4.0 International License (http://creativecommons.org/licenses/by/4.0/), which permits unrestricted use, distribution, and 
Up to now, SCD remains an invalidating chronic disorder with high mortality and morbidity $[7,8]$. The most common acute manifestations of SCD include acute hemolytic crisis and vaso-occlusive crisis (VOCs). VOCs are characterized by musculoskeletal pain, which might develop into severe form such as acute chest syndrome, stroke or priapism [1,3, 9-12]. In addition, with the spleen being one of the target organs of VOC, patients with SCD are also prone to serious bacterial infections due to asplenism $[1,3]$. The recurrent pattern of VOCs results in chronic organ damage, which becomes clinically evident in adult patients [13]. SCD was long regarded as a disease of children, with few surviving to adulthood [14]. Today, thanks to advances in infection control, vaccination and screening programs, as well as intensive disease management, more than $95 \%$ of children with SCD in developed countries reach adulthood [15]. In adults with SCD, survival is estimated to be over 50 years for patients with $\mathrm{HbSS}$ or $\mathrm{HbS} / \mathrm{\Omega}^{0}$-thalassemia genotypes, while the survival of patients with $\mathrm{HbSC}$ or $\mathrm{HbS} / \Omega^{+}$-thalassemia genotypes is close to that of the general population [15].

Epidemiologic and global burden of disease studies have shown that SCD is widespread in sub-Saharan Africa, in the Middle East, Indian subcontinent and some Mediterranean regions. In the last few decades, due to voluntary population migrations, the $\mathrm{HbS}$ gene has spread all over the world. A study published in 2014 estimated that the global number of migrants with $\mathrm{HbS}$ increased from approximately 1.6 million in 1960, to 3.6 million in 2000 [16]. In 2006, the World Health Organization (WHO) recognized hemoglobinopathies, including SCD, as a global public health problem and urged national health systems worldwide to design and establish programs for the prevention and management of SCD [17]. The European Union considers SCD a rare disease.

Changes in the demographic profile of SCD have been also reported in Italy [18-20], a country where SCD, in particular $\mathrm{HbS} / \beta$-thalassemia, is historically present in the native population. We describe here the experience of new challenges posed to Italian health providers by the increasing prevalence of SCD. To this purpose, we will first discuss the changing epidemiology of SCD in Italy, then we will briefly review the peculiarity of the Italian treatment strategy.

\section{Epidemiology of sickle cell disease in Italy}

The prevalence of SCD throughout Italy is changing and the presence of immigrants in the increasing number of SCD patients in Italian regions with a historically low disease prevalence has been documented by recent studies [19-23]. The highest frequency of the sickle cell allele in Italy was reported in Sicily, with an estimated mean frequency of $2 \%$ and peaks as high as $13 \%$ [24]. Notably, in Western Sicily SCD appears to have originated from Africa, with chromosomal analysis of the $\mathrm{HbSS}$ and $\mathrm{HbS} / \beta$-thalassemia genotypes suggesting that the HbSS genotype found in Sicily arrived initially from North African populations [25].

In an Italian survey of 696 cases of SCD, conducted in the late 1990 s, 518 cases $(74 \%)$ were identified as compound heterozygous $\mathrm{HbS} / \mathrm{\beta}$-thalassemia, 149 cases $(21 \%)$ as homozygous HbSS, and 21 cases $(3 \%)$ as compound heterozygous $\mathrm{HbS} /$ other $\mathrm{Hb}$ structural variant [26]. Of the 673 cases of SCD with a known place of residence, $60 \%$ were living in Sicily, 20\% in South Italy, 6\% in Central Italy, and 13\% in North Italy. Hence the survey revealed that, in the 1990s, the majority of SCD patients in Italy resided in Sicily and that they mostly had $\mathrm{HbS} /$ ß-thalassemia. A survey update, published in 2003, found that the proportion of SCD patients living in North Italy had increased to $20 \%$, but in Sicily this had decreased to 53\% [18]. Furthermore, the proportion of patients with HbSS had increased from 21\% in 1998 to $28 \%$ in 2003. A comparison of patients of non-Italian versus Italian origin showed that non-Italian patients were mostly homozygous for the $\mathrm{HbS}$ allele $(72 \%$ vs $18 \%$, respectively), were younger ( $75 \%<18$-years old vs $23 \%$ ) and lived predominantly in North Italy (61\% vs $11 \%)$.

Real-life experience with the use of hydroxyurea (HU) in SCD was assessed using data from a retrospective Italian nationwide survey of SCD patients with heterogeneous descent, which registered 1,638 patients. From a total of 652 patients who had received HU during their disease course, 400 patients (64\%) were Caucasian in origin and 221 patients (36\%) originated from Africa [20]. It is also apparent that the genotype of the $\mathrm{Hb}$ allele in Italy is changing over time with an increasing frequency of the homozygous HbSS genotype. Screening programs initiated in the 1970s in Italy have increased public awareness of thalassemia and aided its prevention in target populations as well as enabling screening for other hemoglobinopathies [27-29]. These programs, which aim to prevent hemoglobinopathies, have significantly reduced the frequency of live births with SCD [27-29]. In Sicily, an 85\% decrease in the incidence of thalassemia major and SCA (from 1 in 245 live births to 1 in 2,000) has been documented following 30 years of preventative actions, which included legislative action, a public awareness campaign, screening and carrier diagnostics, genetic counselling, and prenatal diagnosis [29]. In addition, a universal screening program for hemoglobinopathies, which includes voluntary pregnancy termination within the $22^{\text {nd }}$ week in case of an affected fetus, is active for couples before and/or after conception according to the Italian law since Italy is considered an area endemic for hemoglobinopathies [30]. 
The identification of SCD in refugees at their first admission to an emergency department for an acute disease-related event was assessed in a study coordinated by the Italian Society of Thalassemia and Hemoglobinopathies (SITE). In total, 67 patients with SCD (48\% children, mostly with the HbSS genotype) were identified from a retrospective analysis of data collected from 2014 to 2017 [31]. The main causes of access to the emergency department were VOC (35.8\%), anemia (19.4\%), and fever (7.5\%); $60 \%$ of the identified SCD patients were then followed in reference centers for hemoglobinopathies.

Together, these data suggest that the increased number of patients with SCD in Italy has mostly resulted from migratory patterns of immigrants arriving, in recent years, from countries in which there is a high disease prevalence and that there are approximately 2,000 patients with SCD currently living in Italy.

\section{Management of patients with sickle cell disease in Italy}

The creation of evidence-based guidelines for SCD, as for other uncommon or neglected diseases, has proven challenging due to the complex clinical expression of the disease, and the availability of clinical trials regarding only some screening, management, and monitoring issues of SCD. Notably, an important goal of SCD guidelines is to improve the awareness of SCD and increase the number of health professionals able to provide care for patients with SCD [32].

Effort undertaken over the past 10 years by scientific societies involved in the care of pediatric and adult patients with SCD (the Italian Association of Hematology and Pediatric Oncology [AIEOP] and SITE) has been to develop guidelines for the management of children and adults with SCD, respectively, tailoring international recommendations to the Italian health care system.

In general, currently available guidelines deal with three main areas of SCD management: prevention of infections, stroke, and management of acute and chronic complications; treatment of the various complications (VOC, pain, infections, worsening of anemia, acute chest syndrome, vasculopathy); and specific treatment of severe disease with disease-modifying therapies (transfusion and HU) [32-37].

Preventive measures have a central position in the management of SCD. Prophylactic antibiotics should be initiated as early as 2 months of age in infants and a specific vaccination program should be followed in order to widen the protection against encapsulated bacteria [38, 39].

Primary prevention of stroke is performed by screening children, aged 2 to 16 years, with transcranial Doppler ultrasonography; this allows the identification of children at high risk of stroke, who are placed on transfusions and, eventually, $\mathrm{HU}$ for stroke prevention [40].

The use of chronic transfusions (typically given on a monthly basis) to reduce the percentage of $\mathrm{HbS}$ in the blood have proven effective in preventing most complications of SCD, including stroke, and in minimizing chronic anemia with significant improvements in the patient-centered outcome of health-related quality of life $[1,35,41-44]$. Preliminary results from the "National Transfusion Treatment Survey in patients with SCD" (NCT03397017), a prospective longitudinal systemic study designed to assess the therapeutic approach in a large Italian cohort of patients with $\operatorname{SCD}(n=1,579)$, were reported recently [19]. This national survey, which was coordinated by SITE in collaboration with the Italian Society of Transfusion Medicine and Immunohematology (SIMTI) and AIEOP, showed that $14 \%$ of patients are on regular transfusion, while $40 \%$ received both transfusion and $\mathrm{HU}$, the transfusional approach being similar in $\mathrm{HbSS}, \mathrm{HbS} / \beta^{\circ}$-thalassemia and $\mathrm{HbS} / \beta^{+}$-thalassemia patients, who were predominately Caucasian or African; severe VOCs and symptomatic anemia were the main reasons for transfusion. The rate of red blood cell alloimmunization was comparable to the lower rate reported in the literature [45]. Elderly Caucasian SCD patients and their long-term follow-up represent a unique population of SCD, and are extremely informative on aging with SCD.

The introduction of chronic transfusion in children with cerebrovascular disease as well as the aging of adults with SCD has increased the use of different transfusion regimens (e.g.: simple transfusion, erythrocytapheresis, red blood cell exchange), which might lead to iron overload. The availability of iron chelators, including deferoxamine, given parenterally, and the oral agent deferasirox, has definitively improved clinical management of iron-overload in SCD subjects [46-48]. Notably, long-term iron chelation therapy with deferiprone was associated with a similar efficacy and safety profile to that of deferoxamine in patients with SCD and may therefore represent an effective long-term treatment option [49]. However, it is of note that the oral chelator deferiprone is currently off-label.

In Italy, there is also wide experience in the treatment of SCD with erythrocyte exchange as a means of lowering $\mathrm{HbS}$ levels, particularly in patients who do not tolerate or are unresponsive to HU. Indeed, manual or automatic red blood cell exchange was shown to be safe and effective in preventing complications of SCD for up to 29 years, with minimal development of iron overload and no increased risk of procedure-related complications in both adult and pediatric SCD patients [50-52]. More recently, an Italian double-center retrospective crosssectional study showed that early prophylactic 
erythrocytapheresis (initiated at $10.7 \pm 5.2$ weeks of gestation) improved maternal and fetal outcomes in SCD women with a history of severe SCD-related organ complications [53]. The generation of SITE recommendations for transfusion strategies in hemoglobinopathies has contributed to standardizing the procedures and sharing the clinical indication to the different transfusional approaches at a national level [54]. The real-life transfusion strategy is the object of a very recent survey [19]. A large observational study coordinated by SITE demonstrated the efficacy of direct-acting antiviral drugs in the eradication of hepatitis $\mathrm{C}$ virus (HCV) in an Italian cohort of SCD patients infected with $\mathrm{HCV}$ $(\mathrm{n}=136 ; 93.5 \%$ of these patients achieved a sustained virologic response), which likely occurred due to transfusion therapy prior to the introduction of blooddonor screening in the 1990s [55].

A large body of preclinical and clinical evidence has demonstrated that HU reduces the morbidity and mortality of both adults and children (including infants) with SCD, with a favorable tolerability profile and without significant short-term and long-term safety concerns [56-68]. A series of real-life reports documenting the use of $\mathrm{HU}$ in Italy have recently been published [20, 22, 69]. HU was shown to be beneficial as a treatment option in a retrospective, nationwide cohort study of 1,638 patients with SCD of whom 652 patients had received HU during their disease course [20]. Notably, only $39.8 \%$ of patients $(652$ out of 1,638 patients) with SCD who had attended treatment centers across Italy were treated with $\mathrm{HU}$, suggesting its underutilization in clinical practice. The percentage of $\mathrm{HbS} / \beta^{\circ}$-thalassemia and $\mathrm{HbS} / \beta^{+}$-thalassemia patients on HU was even lower: 90/624 (14.4\%) [19].

A sub-analysis of pediatric data from the retrospective, nationwide cohort study [20] demonstrated the tendency to treat children with lower doses than those recommended; furthermore, although national pediatric guidelines recommend starting $\mathrm{HU}$ treatment as early as the first months of life, this cohort of children revealed that HU was never started before 11 months of age [22]. Nonetheless, the results of this survey highlight good adherence to the Italian National Guidelines that included detailed recommendations for the use of $\mathrm{HU}$, which is noteworthy considering patients were mainly firstgeneration immigrants, who may be socially, culturally, and economically vulnerable [22].

Since VOC are the most common acute manifestations of SCD, the main symptom of which is severe pain, we developed an integrated algorithm to manage acute VOC in the emergency department (ED). In this algorithm we introduced multimodal analgesia as an innovative approach to treat SCD-related pain [35, 70, 71]. Multimodal analgesia allows for a: 1) reduction of side effects since each molecule is used at a lower dosage to obtain the same degree of analgesia of a single molecule at a higher dosage;2) synergistic effect due to blockage of different mechanisms of pain generation; opioid or opioid-like actin modulates central nervous system pain perception whereas non-steroid anti-inflammatory drugs modulate pain of vascular origin and neuroinflammatorymediated pain (ischemia/reperfusion tissue injury) [70, 71]. This approach is particularly important to prevent addiction to opioids, which is a risk of prescribing these drugs for the treatment of VOC-related pain in SCD.

\section{Italian guidelines for the management of children and adults with SCD}

AIEOP published comprehensive and detailed guidelines for the management of SCD in children in 2013 $[33,72]$ and, in 2014 SITE issued recommendations for the treatment of adults with SCD [36]. These recommendations have been conceived as easy-to-consult and practice-oriented guidelines addressing the following topics: prevention of infections and follow-up; treatment of acute events (painful VOC, acute chest syndrome, abdominal pain with biliary dysfunction, infarct or acute cerebrovascular events, priapism, acute anemia and aplastic crisis); management of chronic complications (pulmonary hypertension, bone and joint complications, renal complications, and eye complications); intensive treatment ( $\mathrm{HU}$ and transfusion plus iron chelation).

In addition, great care has been taken by SITE to develop guidelines devoted to complications, such as bone disease, which are typically observed both in adult and pediatric SCD populations [73].

\section{Interactive algorithm for the management of acute events in the emergency department}

SITE coordinated a panel composed of AIEOP, SIMTI, SIMI (Italian Society of Internal Medicine), and SIMEU (Italian Society of Emergency Medicine) and a representative of the nurses to develop an interactive, easy-to-use algorithm for the clinical management of acute events related to SCD in the ED (Figure 1) [35, 74]. The development of guidelines for the triage and management of SCD patients in the ED responds to the need to improve awareness and knowledge of this hemoglobinopathy, characterized by "time dependent" acute manifestations, among health providers working in this setting where the likelihood of encountering SCD patients will continue to increase [35]. Timely and aggressive interventions, like those for the management of stroke in the general population, are strongly recommended to prevent dramatic evolution of symptoms [35]. Evidence shows that the management of acute VOCs in the emergency department becomes more effective if health providers have received training in SCD [75]. 


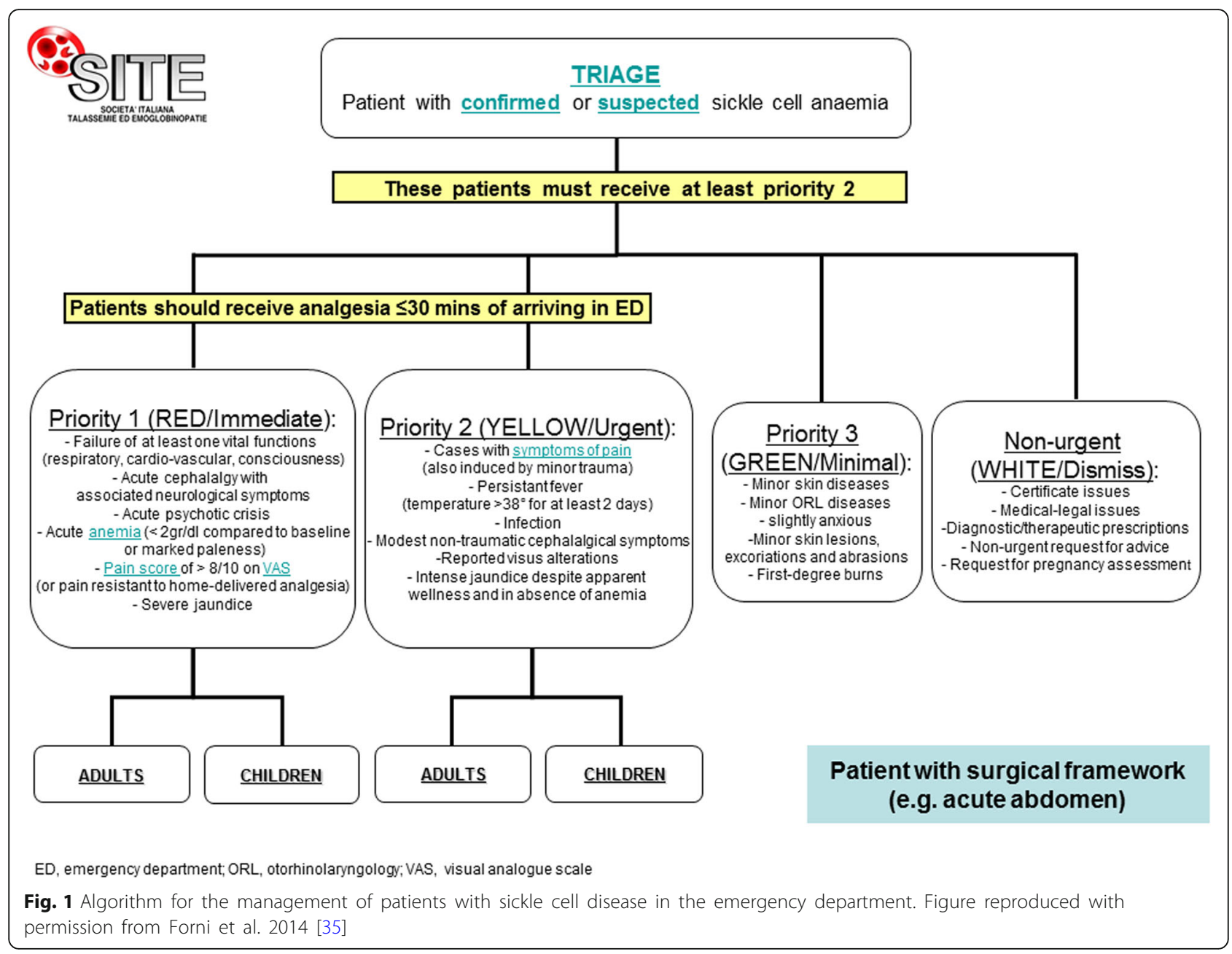

\section{Measures implemented in Italy to handle the increasing prevalence of SCD}

The Italian experience in the management of SCD has grown over the years. In contrast with other countries, this experience has addressed not only HbSS but a number of other genotypes involving ß-thalassemia mutations. Italian centers for hemoglobinopathies have cared for patients with SCD that represent approximately $10 \%$ of the global population with hemoglobinopathies. The background knowledge accumulated by these centers, and their distribution throughout Italy, highlights Italy as an example of a successful network of expert physicians on hemoglobinopathies to optimize patient clinical management. This network has been built since the 1960s together with national programs of prevention and screening. Due to the in- and out-migration fluxes towards large urban centers, the distribution of patients with SCD in regions where historically there was a low prevalence of hemoglobinopathies makes it necessary to widen the national network to these regions and to expand the training of specialists and of informed health providers about this multifaceted disease. The need to reinforce the national network of hemoglobinopathy has been addressed by AIEOP and SITE through the creation, improvement and revision of guidelines tailored to Italy's resources and healthcare system.

In 2017 the Italian government approved a law supporting the institution of a National Thalassemias and Hemoglobinopathies Network [76]. The main objective of this network is to further potentiate the activity of existing clinical centers devoted to hemoglobinopathies and to improve access of patients to highly specialized and comprehensive treatment. Ideally, this should impact positively on the management of SCD in Italy.

It is generally recognized that registries are important tools for detecting demographic patterns, allocating resources, monitoring patient outcomes, and guiding decisions $[23,77,78]$. The creation of an Italian national registry of hemoglobinopathies (Registro nazionale della talassemia e delle emoglobinopatie [National Registry of Thalassemia and Hemoglobinopathies]) was approved in 2017 [79] due to a strong joint action of SITE and national patients associations, and the first national epidemiologic data should be available soon. 
AIEOP and SITE have also joined forces to promote programs of newborn screenings [38]. This preventive measure may be redundant in the presence of effective antenatal and/or prenatal screening programs, considering that specific examination for the diagnosis of hemoglobinopathies are freely available from the National Health Service for all child-bearing age individuals and gynecologists screen all pregnant women who are unaware of their status; however, newborn screening becomes crucial for individuals from high-risk ethnic groups who may be unaware of their carrier status as they were never screened for SCD in their country of origin or if there are situations of segregation that cause pregnancy to be outside of the normal care channels. To date, published evidence concerning newborn screening for SCD in Italy is limited to a few regional pilot projects [30, 80-83]. A scientific discussion has been opened by a recent Pan-European consensus conference on newborn screening for SCD, which involved a panel of $>50$ SCD experts from 13 European countries, and has recently been published [84]. Finally, recent evidence from a retrospective study highlights the importance of SCD screening of refugees, from countries with a high frequency of $\mathrm{HbS}$, on their arrival in Italy [31].

\section{Research activities carried out over the last 10 years in Italy}

Beside the organization of care for patients with SCD, efforts have been made to develop research programs and involve researchers in SCD both in preclinical and clinical studies. This effort was directed on the following topics: genetic aspects of the disease, and its possible reciprocal influence with other genes [85]; mechanisms related to the molecular pathophysiology of the disease [5, 86-94]; prenatal diagnosis, exploring either methods or clinical impact $[29,95]$; iron monitoring [49]; chronic organ damage monitoring, either liver [96, 97], kidney [98], heart [99] or brain [100-103]; cognitive function $[104,105]$.

\section{Conclusions and perspectives}

Overall, the Italian historical experience regarding the global care of hemoglobinopathies is an example of adherence to the recommendations of the WHO to implement comprehensive national programs for the prevention and management of SCD. Alongside this is the institution of the National Thalassemias and Hemoglobinopathies Network [76], which is designed to further potentiate the activity of existing clinical centers devoted to hemoglobinopathies, to improve access of patients to highly specialized and comprehensive treatment in Italy, and to improve the coordination of initiatives and access to new therapeutical approaches. In support of this activity, a number of easy-to-use, practice-oriented and detailed recommendations have been developed by National Scientific Societies. These will no doubt increase the awareness and understanding of SCD among Italian clinicians and further optimize the management of this complex and severe condition. These are ambitious, but feasible, goals and further effort will be required from all professionals involved in the management of SCD. It is possible that the availability of novel drug therapies (crizanlizumab, voxelotor, l-glutamine), bone marrow transplant alternatives from the typical familiar donor (haploidentical, matched unrelated donor), and gene therapy may change the clinical outcome of SCD. As such, a sound national network can facilitate the access of patients to the most appropriate treatment.

\section{Abbreviations \\ AIEOP: Italian Association of Hematology and Pediatric Oncology; $\mathrm{Hb}$ : Hemoglobin; HbS: Sickle hemoglobin; HU: Hydroxyurea; SCA: Sickle cell anemia; SCD: Sickle cell disease; SIMEU: Italian Society of Emergency Medicine; SIMI: Italian Society of Internal Medicine; SIMTI: Society Italian Transfusion Medicine and Immunohematology; SITE: Italian Society of Thalassemia and Hemoglobinopathies; VOC: Vaso-occlusive crisis; WHO: World Health Organization}

\section{Acknowledgements}

Melanie Gatt (PhD) and Lorenza Lanini, independent medical writers, provided medical writing assistance on behalf of Springer Healthcare Communications. Novartis Farma S.p.A. provided financial support for this writing assistance.

\section{Authors' contributions}

GR and GLF conceptualized, drafted and approved the final manuscript, and provided the intellectual content of the presented data. LDF, RC, PR, SP, W, GP, CF, AQ, GG, APie, VP, GBR, FS, DV, MC, FF, LS, MDC, AP, AM contributed to the collection of data, and approved the final manuscript.

Funding

Medical writing assistance was funded by Novartis Farma S.p.A.

Availability of data and materials

Not applicable

Ethics approval and consent to participate

Not applicable

Consent for publication

Not applicable

Competing interests

All Authors participated on an Advisory Board for Novartis

\section{Author details}

'Oncoematologia Pediatrica, Azienda Policlinico-Vittorio Emanuele, Università di Catania, Via Santa Sofia 78, 95123 Catania, Italy. ²Dipartimento di Medicina, Sezione Medicina Interna, Università di Verona, Policlinico GB Rossi, AOUI, Verona, Italy. ${ }^{3}$ Clinica di Oncoematologia Pediatrica, Dipartimento della Salute della Donna e del Bambino Azienda Ospedaliera, Università di Padova, Padova, Italy. ${ }^{4}$ U.O.C Ematologia e Malattie Rare del Sangue e degli Organi Ematopoietici-P.O. Cervello Palermo, Palermo, Italy. ${ }^{5}$ Dipartimento della Donna, del Bambino e di Chirurgia Generale e Specialistica, Università degli Studi della Campania "Luigi Vanvitelli", Napoli, Italy. ${ }^{6}$ Dipartimento di Scienze Cliniche e Biologiche, Università di Torino, Ospedale San Luigi Gonzaga, Orbassano, Italy. ${ }^{7}$ Dipartimento Integrato Materno Infantile U. O. Complessa di Pediatria Università degli Studi di Modena e Reggio Emilia, Modena, Italy. ${ }^{8}$ Unità operativa semplice Studio Emoglobinopatie Simt, Ragusa, Italy. ${ }^{9}$ U.O.S talassemia PO Vittorio Emanuele, Gela, Italy. ${ }^{10}$ UOC di Medicina Generale, Centro Malattie Rare Fondazione IRCCS Ca' Granda Ospedale Maggiore 
Policlinico Pad, Granelli, Milano, Italy. ${ }^{11}$ Dipartimento di Scienze Mediche e Chirurgiche Materno-Infantili e dell'Adulto, Università degli Studi di Modena e Reggio Emilia, Modena, Italy. ${ }^{12}$ Centro della Microcitemia e delle Anemie Congenite, Ospedale Galliera, Via Volta 6, 16128 Genova, Italy. ${ }^{13}$ U.O. Ematologia con Talassemia ARNAS Civico Di Cristina Benfratelli, Palermo, Italy. ${ }^{14}$ U.O. Talassemici Centro Anemia Rare e Disturbi del metabolismo del Ferro ASL ROMA 2 Ospedale S Eugenio, Roma, Italy. ${ }^{15}$ Struttura Complessa di Immuno-trasfusionale Azienda Ospedaliero, Universitaria di Modena, Modena, Italy. ${ }^{16}$ Struttura Complessa di Pediatria-Microcitemie dell'Ospedale San Luigi di Orbassano, Orbassano, TO, Italy.

\section{Received: 20 March 2019 Accepted: 19 May 2019}

\section{Published online: 30 May 2019}

\section{References}

1. Ware RE, de Montalembert M, Tshilolo L, Abboud MR. Sickle cell disease. Lancet. 2017;390(10091):311-23.

2. Silvestroni E, Bianco I. Una nuova entità nosologica: la malattia microdrepanocitica. Haematol Lat. 1946;29:455-88.

3. Rees DC, Williams TN, Gladwin MT. Sickle-cell disease. Lancet. 2010; 376(9757):2018-31

4. De Franceschi L, Cappellini MD, Olivieri O. Thrombosis and sickle cell disease. Semin Thromb Hemost. 2011;37(3):226-36

5. Matte A, Recchiuti A, Federti E, Koehl B, Mintz T, El Nemer W, et al. Resolution of sickle cell disease-associated inflammation and tissue damage with 17R-resolvin D1. Blood. 2019;133(3):252-65.

6. Matte A, Zorzi F, Mazzi F, Federti E, Olivieri O, De Franceschi L. New Therapeutic Options for the Treatment of Sickle Cell Disease. Mediterr J Hematol Infect Dis. 2019;11(1):e2019002.

7. Kato GJ, Piel FB, Reid CD, Gaston MH, Ohene-Frempong K, Krishnamurti L, et al. Sickle cell disease. Nat Rev Dis Primers. 2018;4:18010.

8. Modell B, Darlison M. Global epidemiology of haemoglobin disorders and derived service indicators. Bull World Health Organ. 2008;86(6):480-7.

9. Manwani D, Frenette PS. Vaso-occlusion in sickle cell disease: pathophysiology and novel targeted therapies. Blood. 2013;122(24):3892-8

10. Jacob E, Beyer JE, Miaskowski C, Savedra M, Treadwell M, Styles L. Are there phases to the vaso-occlusive painful episode in sickle cell disease? J Pain Symptom Manage. 2005;29(4):392-400.

11. Ballas SK. The sickle cell painful crisis in adults: phases and objective signs. Hemoglobin. 1995;19(6):323-33.

12. Ballas SK, Smith ED. Red blood cell changes during the evolution of the sickle cell painful crisis. Blood. 1992;79(8):2154-63.

13. DeBaun MR, Kirkham FJ. Central nervous system complications and management in sickle cell disease. Blood. 2016;127(7):829-38.

14. Ballas SK, Gupta K, Adams-Graves P. Sickle cell pain: a critical reappraisal. Blood. 2012:120(18):3647-56.

15. Gardner K, Douiri A, Drasar E, Allman M, Mwirigi A, Awogbade M, et al. Survival in adults with sickle cell disease in a high-income setting. Blood. 2016;128(10):1436-8

16. Piel FB, Tatem AJ, Huang Z, Gupta S, Williams TN, Weatherall DJ. Global migration and the changing distribution of sickle haemoglobin: a quantitative study of temporal trends between 1960 and 2000. Lancet Glob Health. 2014;2(2):e80-9.

17. World Health Organization. Sickle-cell anaemia. http://apps.who.int/iris/ bitstream/handle/10665/20890/A59_9-en.pdf?sequence=1\&isAllowed=y. Accessed 2 Nov 2018.

18. Russo-Mancuso G, La Spina M, Schiliro G. The changing profile of sickle cell disease in Italy. Eur J Epidemiol. 2003;18(9):923-4.

19. Graziadei G, Sainati L, Bonomo P, Venturelli D, Masera N, Casale M, et al. Transfusion Therapy in a Multi-Ethnic Sickle Cell Population RealWorld Practice. A Preliminary Data Analysis of Multicentre Survey. Blood. 2018;132:2389.

20. Rigano P, De Franceschi L, Sainati L, Piga A, Piel FB, Cappellini MD, et al. Real-life experience with hydroxyurea in sickle cell disease: A multicenter study in a cohort of patients with heterogeneous descent. Blood Cells Mol Dis. 2018:69:82-9.

21. Colombatti R, Dalla Pozza LV, Mazzucato M, Sainati L, Pierobon M, Facchin P. Hospitalization of children with sickle cell disease in a region with increasing immigration rates. Haematologica. 2008;93(3):463-4.

22. Colombatti R, Palazzi G, Masera N, Notarangelo LD, Bonetti E, Samperi $P$, et al. Hydroxyurea prescription, availability and use for children with sickle cell disease in Italy: Results of a National Multicenter survey. Pediatr Blood Cancer. 2018;65(2):e26774.

23. Inusa BPD, Colombatti R. European migration crises: The role of national hemoglobinopathy registries in improving patient access to care. Pediatr Blood Cancer. 2017;64(7):e26515.

24. Schiliro G. Sicily: the world reservoir for thalassemias and haemoglobinopathies. Nature. 1978;276(5690):761.

25. Sammarco P, Giambona A, Lo Gioco P, Di Marzo R, Maggio A. Evidence of the African origin of sickle cell hemoglobin in western Sicily. Hemoglobin. 1988;12(2):193-6.

26. Russo-Mancuso G, Romeo MA, Guardabasso V, Schiliro G. Survey of sickle cell disease in Italy. Haematologica. 1998:83(10):875-81.

27. Cao A, Galanello R, Rosatelli MC, Argiolu F, De Virgiliis S. Clinical experience of management of thalassemia: the Sardinian experience. Semin Hematol. 1996:33(1):66-75.

28. Cao A, Rosatelli MC, Galanello R. Control of beta-thalassaemia by carrier screening, genetic counselling and prenatal diagnosis: the Sardinian experience. Ciba Found Symp. 1996;197:137-51 discussion 51-5.

29. Giambona A, Damiani G, Vinciguerra M, Jakil C, Cannata M, Cassara F, et al. Incidence of haemoglobinopathies in Sicily: the impact of screening and prenatal diagnosis. Int J Clin Pract. 2015;69(10):1129-38.

30. Lodi M, Bigi E, Palazzi G, Vecchi L, Morandi R, Setti M, et al. Universal Screening Program in Pregnant Women and Newborns at-Risk for Sickle Cell Disease: First Report from Northern Italy. Hemoglobin. 2017; 41(4-6):230-3.

31. De Franceschi L, Lux C, Piel FB, Gianesin B, Bonetti F, Casale M, et al. Access to emergency department for acute events and identification of sickle cell disease in refugees. Blood. 2019:[Epub ahead of print].

32. Yawn BP, Buchanan GR, Afenyi-Annan AN, Ballas SK, Hassell KL, James AH, et al. Management of sickle cell disease: summary of the 2014 evidencebased report by expert panel members. JAMA. 2014;312(10):1033-48.

33. Colombatti R, Perrotta S, Samperi P, Casale M, Masera N, Palazzi G, et al. Organizing national responses for rare blood disorders: the Italian experience with sickle cell disease in childhood. Orphanet J Rare Dis. 2013;8:169.

34. de Montalembert $M$, Ferster A, Colombatti $R$, Rees DC, Gulbis B. European Network for $\mathrm{R}$, et al. ENERCA clinical recommendations for disease management and prevention of complications of sickle cell disease in children. Am J Hematol. 2011;86(1):72-5.

35. Forni GL, Finco G, Graziadei G, Balocco M, Rigano P, Perrotta S, et al. Development of interactive algorithm for clinical management of acute events related to sickle cell disease in emergency department. Orphanet J Rare Dis. 2014:9:91.

36. Societa' Italiana Talassemie ed Emoglobinopatie (SITE). Recommendations for the management of adult patients with sickle cell anemia (Raccomandazioni per la gestione del paziente adulto affetto da anemia falciforme). №2 - 2014. . http://www.site-italia.org/ collana_scientifica.php. Accessed 1 Nov 2018.

37. Beyer JE, Platt AF, Kinney TR, Treadwell M. Practice guidelines for the assessment of children with sickle cell pain. J Soc Pediatr Nurs. 1999; 4(2):61-73.

38. Societa' Italiana Talassemie ed Emoglobinopatie (SITE). Recommendations for neonatal screening in sickle cell syndromes of the Italian Thalassemia and Hemoglobinopathy Society (SITE) and the Italian Association of Hematology and Pediatric Oncology (AIEOP) (Raccomandazioni per lo screening neonatale nelle sindromi falciformi della Società Italiana Talassemie ed Emoglobinopatie (SITE) e della Associazione Italiana di Ematologia ed Oncologia Pediatrica (AIEOP). N ${ }^{\circ}$ 5 - 2017. http://www.site-italia.org/collana_scientifica.php. Accessed 1 Nov 2018.

39. Hirst C, Owusu-Ofori S. Prophylactic antibiotics for preventing pneumococcal infection in children with sickle cell disease. Cochrane Database Syst Rev. 2014;11:CD003427.

40. Beyer JE, Simmons LE, Woods GM, Woods PM. A chronology of pain and comfort in children with sickle cell disease. Arch Pediatr Adolesc Med. 1999; 153(9):913-20.

41. Adams RJ, McKie VC, Hsu L, Files B, Vichinsky E, Pegelow C, et al. Prevention of a first stroke by transfusions in children with sickle cell anemia and abnormal results on transcranial Doppler ultrasonography. N Engl J Med. 1998;339(1):5-11. 
42. DeBaun MR, Gordon M, McKinstry RC, Noetzel MJ, White DA, Sarnaik SA, et al. Controlled trial of transfusions for silent cerebral infarcts in sickle cell anemia. N Engl J Med. 2014;371(8):699-710.

43. Adams RJ, Brambilla D. Optimizing Primary Stroke Prevention in Sickle Cell Anemia Trial I. Discontinuing prophylactic transfusions used to prevent stroke in sickle cell disease. N Engl J Med. 2005;353(26):2769-78.

44. Beverung LM, Strouse JJ, Hulbert ML, Neville K, Liem RI, Inusa B, et al. Health-related quality of life in children with sickle cell anemia: impact of blood transfusion therapy. Am J Hematol. 2015;90(2):139-43.

45. Russo-Mancuso G, Sciotto A, Munda SE, Romano V, Schilirò G. Alloimmunization and autoimmunity in Caucasian patients with sickle cell disease. Int J Pediatr Hematol Oncol. 1998;5:443-7.

46. Poggiali E, Cassinerio E, Zanaboni L, Cappellini MD. An update on iron chelation therapy. Blood Transfus. 2012;10(4):411-22.

47. Vichinsky E, Bernaudin F, Forni GL, Gardner R, Hassell K, Heeney MM, et al. Long-term safety and efficacy of deferasirox (Exjade) for up to 5 years in transfusional iron-overloaded patients with sickle cell disease. $\mathrm{Br} J$ Haematol. 2011;154(3):387-97.

48. Vichinsky E, Torres M, Minniti CP, Barrette S, Habr D, Zhang Y, et al. Efficacy and safety of deferasirox compared with deferoxamine in sickle cell disease: two-year results including pharmacokinetics and concomitant hydroxyurea. Am J Hematol. 2013;88(12):1068-73.

49. Calvaruso G, Vitrano A, Di Maggio R, Ballas S, Steinberg MH, Rigano P, et al. Deferiprone versus deferoxamine in sickle cell disease: results from a 5-year long-term Italian multi-center randomized clinical trial. Blood Cells Mol Dis. 2014;53(4):265-71.

50. Cabibbo S, Fidone C, Garozzo G, Antolino A, Manenti GO, Bennardello F, et al. Chronic red blood cell exchange to prevent clinical complications in sickle cell disease. Transfus Apher Sci. 2005;32(3):315-21.

51. Carrara P, Balocco M, Pinto V, Olcese F, Solda A, Strada P, et al. Manual erythroexchange for chronic transfusion therapy in patients with sickle cell syndromes unresponsive to hydroxyurea: a long-term follow-up. Am J Hematol. 2010;85(12):974

52. Masera N, Tavecchia L, Pozzi L, Riva F, Vimercati C, Calabria M, et al. Periodic erythroexchange is an effective strategy for high risk paediatric patients with sickle-cell disease. Transfus Apher Sci. 2007;37(3):241-7.

53. Vianello A, Vencato E, Cantini M, Zanconato G, Manfrin E, Zamo A, et al. Improvement of maternal and fetal outcomes in women with sickle cell disease treated with early prophylactic erythrocytapheresis. Transfusion (Paris). 2018;58(9):2192-201.

54. Societa' Italiana Talassemie ed Emoglobinopatie (SITE). Recommendations for transfusion strategies in hemoglobinopathies (Raccomandazioni per le strategie trasfusionali nelle Emoglobinopatie). №3 - 2014. http://www.siteitalia.org/collana_scientifica.php. Accessed 1 Nov 2018.

55. Origa R, Ponti ML, Filosa A, Galeota Lanza A, Piga A, Saracco GM, et al. Treatment of hepatitis $C$ virus infection with direct-acting antiviral drugs is safe and effective in patients with hemoglobinopathies. Am J Hematol. 2017;92(12):1349-55

56. Charache S, Terrin ML, Moore RD, Dover GJ, Barton FB, Eckert SV, et al. Effect of hydroxyurea on the frequency of painful crises in sickle cell anemia. Investigators of the Multicenter Study of Hydroxyurea in Sickle Cell Anemia. N Engl J Med. 1995;332(20):1317-22.

57. Kinney TR, Helms RW, O'Branski EE, Ohene-Frempong K, Wang W, Daeschner C, et al. Safety of hydroxyurea in children with sickle cell anemia: results of the HUG-KIDS study, a phase I/II trial. Pediatric Hydroxyurea Group. Blood. 1999;94(5):1550-4.

58. Lobo CL, Pinto JF, Nascimento EM, Moura PG, Cardoso GP, Hankins JS. The effect of hydroxcarbamide therapy on survival of children with sickle cell disease. Br J Haematol. 2013;161(6):852-60.

59. McGann PT, Ware RE. Hydroxyurea for sickle cell anemia: what have we learned and what questions still remain? Curr Opin Hematol. 2011; 18(3):158-65

60. Rana S, Houston PE, Wang WC, lyer RV, Goldsmith J, Casella JF, et al. Hydroxyurea and growth in young children with sickle cell disease. Pediatrics. 2014;134(3):465-72.

61. Steinberg MH, McCarthy WF, Castro O, Ballas SK, Armstrong FD, Smith W, et al. The risks and benefits of long-term use of hydroxyurea in sickle cell anemia: A 17.5 year follow-up. Am J Hematol. 2010;85(6):403-8.

62. Stettler N, McKiernan CM, Melin CQ, Adejoro OO, Walczak NB. Proportion of adults with sickle cell anemia and pain crises receiving hydroxyurea. JAMA. 2015;313(16):1671-2.
63. Voskaridou E, Christoulas D, Bilalis A, Plata E, Varvagiannis K, Stamatopoulos $\mathrm{G}$, et al. The effect of prolonged administration of hydroxyurea on morbidity and mortality in adult patients with sickle cell syndromes: results of a 17-year, single-center trial (LaSHS). Blood. 2010;115(12):2354-63.

64. Wang WC, Helms RW, Lynn HS, Redding-Lallinger R, Gee BE, OheneFrempong $\mathrm{K}$, et al. Effect of hydroxyurea on growth in children with sickle cell anemia: results of the HUG-KIDS Study. J Pediatr. 2002;140(2):225-9.

65. Wang WC, Ware RE, Miller ST, lyer RV, Casella JF, Minniti CP, et al. Hydroxycarbamide in very young children with sickle-cell anaemia: a multicentre, randomised, controlled trial (BABY HUG). Lancet. 2011; 377(9778):1663-72.

66. Ware RE, Davis BR, Schultz WH, Brown RC, Aygun B, Sarnaik S, et al. Hydroxycarbamide versus chronic transfusion for maintenance of transcranial doppler flow velocities in children with sickle cell anaemia-TCD With Transfusions Changing to Hydroxyurea (TWiTCH): a multicentre, openlabel, phase 3, non-inferiority trial. Lancet. 2016;387(10019):661-70.

67. Ware RE, Helms RW, Investigators SW. Stroke With Transfusions Changing to Hydroxyurea (SWiTCH). Blood. 2012;119(17):3925-32.

68. Wong TE, Brandow AM, Lim W, Lottenberg R. Update on the use of hydroxyurea therapy in sickle cell disease. Blood. 2014;124(26):3850-7 quiz 4004.

69. Di Maggio R, Hsieh MM, Zhao X, Calvaruso G, Rigano P, Renda D, et al. Chronic Administration of Hydroxyurea (HU) Benefits Caucasian Patients with Sickle-Beta Thalassemia. Int J Mol Sci. 2018;19(3):681.

70. De Franceschi L, Finco G, Vassanelli A, Zaia B, Ischia S, Corrocher R. A pilot study on the efficacy of ketorolac plus tramadol infusion combined with erythrocytapheresis in the management of acute severe vaso-occlusive crises and sickle cell pain. Haematologica. 2004;89(11):1389-91.

71. De Franceschi L, Mura P, Schweiger V, Vencato E, Quaglia FM, Delmonte L, et al. Fentanyl Buccal Tablet: A New Breakthrough Pain Medication in Early Management of Severe Vaso-Occlusive Crisis in Sickle Cell Disease. Pain Pract. 2016;16(6):680-7.

72. Associazione Italiana Ematologia Oncologia Pediatrica (AIEOP). Guidelines for the Management of the Drepanocytic Disease in Age Pediatric in Italy (Linee-Guida per la Gestione Della Malattia Drepanocitica in eta' Pediatrica in Italia). www.aieop.org/web/wp-content/uploads/2018/03/Linee-guidaAieop-SCD-2018.pdf. Accessed 1 Nov 2018.

73. Societa' Italiana Talassemie ed Emoglobinopatie (SITE). Recommendations for the management of metabolic bone diseases in hemoglobinopathies (Raccomandazioni per il management delle malattie metaboliche dell'osso nelle emoglobinopatie). №4 - 2016. http://www.site-italia.org/collana_ scientifica.php. Accessed 1 Nov 2018.

74. Societa' Italiana Talassemie ed Emoglobinopatie (SITE). Algorithm for the management of acute events in patients with sickle cell anemia (Algoritmo per la gestione in Pronto Soccorso degli Eventi Acuti nei pazienti affetti da Anemia Falciforme). http://www.site-italia.org/ protocolli.php. Accessed 1 Nov 2018.

75. Po C, Colombatti R, Cirigliano A, Da Dalt L, Agosto C, Benini F, et al. The management of sickle cell pain in the emergency department: a priority for health systems. Clin J Pain. 2013;29(1):60-3.

76. Laws and other regulatory acts. http://fidas.it/wp/wp-content/uploads/2010/ 03/Legge-27.12.2017-n.-205-Legge-di-bilancio-2018-Estratto.pdf. Accessed 1 Nov 2018.

77. Hulihan MM, Feuchtbaum L, Jordan L, Kirby RS, Snyder A, Young W, et al. State-based surveillance for selected hemoglobinopathies. Genet Med. 2015; 17(2):125-30.

78. Modell B, Khan M, Darlison M, King A, Layton M, Old J, et al. A national register for surveillance of inherited disorders: beta thalassaemia in the United Kingdom. Bull World Health Organ. 2001;79(11):1006-13.

79. Italian Republic. Official Journal of the Italian Republic. Rome - Friday, 12 May 2017 (Gazzetta Ufficiale Della Repubblica Italiana Roma - Venerdì, 12 maggio 2017). http://www.gazzettaufficiale.it/eli/gu/2017/05/12/109/sg/pdf. Accessed 1 Nov 2018.

80. Ballardini E, Tarocco A, Marsella M, Bernardoni R, Carandina G, Melandri C, et al. Universal neonatal screening for sickle cell disease and other haemoglobinopathies in Ferrara. Italy. Blood Transfus. 2013;11(2):245-9.

81. Rolla R, Castagno M, Zaffaroni M, Grigollo B, Colombo S, Piccotti S, et al. Neonatal screening for sickle cell disease and other hemoglobinopathies in "the changing Europe". Clin Lab. 2014;60(12):2089-93.

82. Venturelli D, Lodi M, Palazzi G, Bergonzini G, Doretto G, Zini A, et al. Sickle cell disease in areas of immigration of high-risk populations: a low cost and 
reproducible method of screening in northern Italy. Blood Transfus. 2014; 12(3):346-51.

83. Colombatti R, Martella M, Cattaneo L, Viola G, Cappellari A, Bergamo C, et al. Results of a multicenter universal newborn screening program for sickle cell disease in Italy: a call to action. Abstract PB2373. 23rd Congress of the European Hematology Association, Stockholm 14-17 June, 2018. https:// learningcenter.ehaweb.org/eha/2018/stockholm/216864/raffaella.colombatti. results.of.a.multicenter.universal.newborn.screening.html?f=menu=6* $6^{*} \mathrm{ce}$ $i d=1346 * 0$ t_id $=19069^{*}$ media=3*marker=168. Accessed 27 Nov 2018.

84. Lobitz S, Telfer P, Cela E, Allaf B, Angastiniotis M, Backman Johansson $C$, et al. Newborn screening for sickle cell disease in Europe: recommendations from a Pan-European Consensus Conference. $\mathrm{Br} J$ Haematol. 2018:183(4):648-60.

85. Listi F, Sclafani S, Agrigento V, Barone R, Maggio A, D'Alcamo E. Study on the Role of Polymorphisms of the SOX-6 and MYB Genes and Fetal Hemoglobin Levels in Sicilian Patients with beta-Thalassemia and Sickle Cell Disease. Hemoglobin. 2018:42(2):103-7.

86. Biondani A, Turrini F, Carta F, Matte A, Filippini A, Siciliano A, et al. Heatshock protein-27, -70 and peroxiredoxin-II show molecular chaperone function in sickle red cells: Evidence from transgenic sickle cell mouse model. Proteomics Clin Appl. 2008;2(5):706-19.

87. Dalle Carbonare L, Matte A, Valenti MT, Siciliano A, Mori A, Schweiger V, et al. Hypoxia-reperfusion affects osteogenic lineage and promotes sickle cell bone disease. Blood. 2015;126(20):2320-8.

88. De Franceschi L, Franco RS, Bertoldi M, Brugnara C, Matte A, Siciliano A, et al. Pharmacological inhibition of calpain-1 prevents red cell dehydration and reduces Gardos channel activity in a mouse model of sickle cell disease. FASEB J. 2013;27(2):750-9.

89. Kalish BT, Matte A, Andolfo I, Iolascon A, Weinberg O, Ghigo A, et al. Dietary omega-3 fatty acids protect against vasculopathy in a transgenic mouse model of sickle cell disease. Haematologica. 2015;100(7):870-80.

90. Pecoraro A, Rigano P, Troia A, Calzolari R, Scazzone C, Maggio A, et al. Quantification of HBG mRNA in primary erythroid cultures: prediction of the response to hydroxyurea in sickle cell and beta-thalassemia. Eur J Haematol. 2014;92(1):66-72

91. Pecoraro A, Troia A, Calzolari R, Scazzone C, Rigano P, Martorana A, et al. Efficacy of Rapamycin as Inducer of $\mathrm{Hb} F$ in Primary Erythroid Cultures from Sickle Cell Disease and beta-Thalassemia Patients. Hemoglobin. 2015;39(4): 225-9.

92. Siciliano A, Malpeli G, Platt OS, Lebouef C, Janin A, Scarpa A, et al. Abnormal modulation of cell protective systems in response to ischemic/reperfusion injury is important in the development of mouse sickle cell hepatopathy. Haematologica. 2011;96(1):24-32.

93. Siciliano A, Turrini F, Bertoldi M, Matte A, Pantaleo A, Olivieri O, et al. Deoxygenation affects tyrosine phosphoproteome of red cell membrane from patients with sickle cell disease. Blood Cells Mol Dis. 2010;44(4):233-42.

94. Vinchi F, De Franceschi L, Ghigo A, Townes T, Cimino J, Silengo L, et al. Hemopexin therapy improves cardiovascular function by preventing hemeinduced endothelial toxicity in mouse models of hemolytic diseases. Circulation. 2013;127(12):1317-29.

95. Giambona A, Damiani G, Leto F, Jakil C, Renda D, Cigna V, et al. Embryofetal erythroid cell selection from celomic fluid allows earlier prenatal diagnosis of hemoglobinopathies. Prenat Diagn. 2016;36(4):375-81.

96. Pinto VM, Gianesin B, Balocco M, Bacigalupo L, Forni GL. Noninvasive monitoring of liver fibrosis in sickle cell disease: Longitudinal observation of a cohort of adult patients. Am J Hematol. 2017;92(12):E666-E8.

97. Vitrano A, Calvaruso G, Tese L, Gioia F, Cassara F, Campisi S, et al. Real-life experience with liver iron concentration R2 MRI measurement in patients with hemoglobinopathies: baseline data from LICNET. Eur J Haematol. 2016; 97(4):361-70.

98. Lippi G, De Franceschi L, Salvagno GL, Montagnana M, Guidi GC. Estimation of glomerular filtration rate by the modification of diet in renal disease (MDRD) equation in patients with sickle cell disease. Clin Chem Lab Med. 2008;46(8):1200-1.

99. Lippi G, De Franceschi L, Salvagno GL, Pavan C, Montagnana M, Guidi GC. Cardiac troponin T during sickle cell crisis. Int J Cardiol. 2009;136(3):357-8.

100. Colombatti R, De Bon E, Bertomoro A, Casonato A, Pontara E, Omenetto E, et al. Coagulation activation in children with sickle cell disease is associated with cerebral small vessel vasculopathy. PLoS One. 2013;8(10):e78801.

101. Colombatti R, Lucchetta M, Montanaro M, Rampazzo P, Ermani M, Talenti G, et al. Cognition and the Default Mode Network in Children with Sickle Cell
Disease: A Resting State Functional MRI Study. PLoS One. 2016;11(6): e0157090.

102. Rigano P, Pecoraro A, Calvaruso G, Steinberg MH, lannello S, Maggio A. Cerebrovascular events in sickle cell-beta thalassemia treated with hydroxyurea: a single center prospective survey in adult Italians. Am J Hematol. 2013;88(11):E261-4.

103. Graziadei G, Casoni FM, Annoni F, Cortinovis I, Ridolfi P, Gandolfi I, et al. Transcranial color Doppler in stroke-free adult patients with sickle cell disease. Ann Hematol. 2017;96(9):1547-55.

104. Arfe B, Montanaro M, Mottura E, Scaltritti M, Manara R, Basso G, et al. Selective Difficulties in Lexical Retrieval and Nonverbal Executive Functioning in Children With HbSS Sickle Cell Disease. J Pediatr Psychol. 2018:43(6):666-77.

105. Montanaro M, Colombatti R, Pugliese M, Migliozzi C, Zani F, Guerzoni ME, et al. Intellectual function evaluation of first generation immigrant children with sickle cell disease: the role of language and sociodemographic factors. Ital J Pediatr. 2013:39:36.

\section{Publisher's Note}

Springer Nature remains neutral with regard to jurisdictional claims in published maps and institutional affiliations.
Ready to submit your research? Choose BMC and benefit from:

- fast, convenient online submission

- thorough peer review by experienced researchers in your field

- rapid publication on acceptance

- support for research data, including large and complex data types

- gold Open Access which fosters wider collaboration and increased citations

- maximum visibility for your research: over $100 \mathrm{M}$ website views per year

At BMC, research is always in progress.

Learn more biomedcentral.com/submissions 